\title{
REPUBLICANISMO: VITALIDADE DE UM CONCEITO À LUZ DAS HERANÇAS DA MODERNIDADE
}

\section{REPUBLICANISM: THE VITALITY OF A CONCEPT IN THE LIGHT OF THE INHERITANCES OF THE MODERN AGE}

\author{
Livia Scheiner * \\ Rafael Cláudio Simões**
}

\begin{abstract}
RESUMO
Recuperar a dimensão histórica da ideia de republicanismo torna-se, atualmente, uma necessária contribuição dos estudos históricos para a compreensão das tradições e dos elementos contemporâneos que estão envoltos neste conceito. Dimensionar a sua construção desde as repúblicas italianas, no Renascimento, passando pela Revolução Inglesa do século XVII até chegar às revoluções Americana e Francesa do século XVIII, com suas discussões centradas nas ideias de liberdade, virtude cívica e participação, permite-nos aquilatar, para além da formação do próprio conjunto de valores desse ideário, as disputas e apropriações que rondam este conceito na atualidade. Por meio da análise de escritos políticos clássicos da Modernidade inglesa e francesa e à luz da presente historiografia sobre o tema, o presente artigo pretende adensar a reflexão sobre as heranças modernas das atuais apropriações do republicanismo como construto teórico e como prática politica.
\end{abstract}

PALAVRAS-CHAVE: Ideias politicas. Modernidade. Republicanismo. Cidadania.

\begin{abstract}
Recovering the historical dimension of the idea of republicanism has become, today, a necessary contribution of historical studies to the understanding of the traditions and contemporary elements that are involved in this concept. Dimensioning its construction, from the Italian republics, in the Renaissance, passing through the English Revolution of the 17th century, until we reach the American and French revolutions of the 18th century, whose discussions were based on the ideas of freedom, civic virtue and participation, allows us to assess, beyond the formation of the very set of values of this ideal, the disputes and appropriations that surround this concept today. Through the analysis of classic political writings of English and French during the Modern Age and, in the light of the present historiography on the subject, this article intends to deepen the reflection on the modern inheritances of the current appropriations of republicanism as a theoretical construct and as a political practice.
\end{abstract}

KEYWORDS: Political ideas. Modernity. Republicanism. Citizenship.

\footnotetext{
* Professora de História do Colégio D. Pedro II - RJ. Doutora em Ciências da Educação pela Universidad Politécnica y Artística del Paraguay (UPAP). Mestre em História pela Universidade Federal Fluminense (UFF) e Doutoranda em História pela Universidade Federal do Espírito Santo (UFES). E-mail: liviascheiner23@gmail.com

** Professor da Universidade Vila Velha (UVV). Mestre e Doutorando em História pela Universidade Federal do Espírito Santo (UFES). E-mail: rafaelclaudio@gmail.com
} 


\section{INTRODUÇÃO}

O republicanismo, como ideia e prática, remonta à Antiguidade greco-romana, quando valores como os de participação popular nos destinos da coletividade, de soberania do povo, de liberdade do indivíduo, de atuação nos assuntos públicos, de virtude e de democracia começaram a se delinear, em que pese o fato de, naquele contexto, estarem estreitamente demarcados os limites de quem deveria ser considerado ou não cidadão da República. Contudo, ao longo da história de diversas sociedades, especialmente no espectro cristão ocidental, tal conceito irá se aprofundar, ganhar novos contornos, incorporar novas discussões e proposições. Desta forma, não é possível falar de continuidades imediatas entre o republicanismo da Antiguidade e o contemporâneo, e nem mesmo de um desenvolvimento progressivo que o una ao mundo atual. Como alerta Norberto Luiz Guarinello (2003, p. 29), "são mundos diferentes, com sociedades distintas, nas quais pertencimento, participação e direitos têm sentidos diversos."

Sem menosprezar as importantes reflexões desenvolvidas, por exemplo, por Aristóteles e Cícero, apenas para citar dois destacados pensadores antigos, voltaremos nossa atenção às apropriações e ressignificações dos temas da Antiguidade no contexto do mundo moderno e às questões que foram colocadas em cada momento significativo de inserção do republicanismo da vida pública. Interessa-nos acompanhar de que modo as ideias de cidadania, participação e direitos se inscrevem na experiência histórica dos Estados Nacionais, assim como seus desdobramentos no ideário republicano contemporâneo. Aqui, destaque-se, pretendemos, especialmente, pensar nas contribuições advindas das lutas políticas na Inglaterra, no século XVII, e das duas grandes revoluções do fim do século XVIII: a Americana (1776) e a Francesa (1789). Estas serão as inflexões a partir das quais passaremos a refletir, mesmo que brevemente, sobre a presença da temática republicana, bem como das ideias políticas a ela subjacentes, nas sociedades do século XXI.

\section{O HUMANISMO CÍVICO RENASCENTISTA}

De modo geral, podemos dizer que o Renascimento foi o resultado de inúmeras mudanças que aconteceram na Europa - na Península Itálica, de modo específico - entre os séculos XIV e XV. Foi na península, principalmente em Florença, que o humanismo cívico floresceu. Entre os seus elementos centrais, o movimento renascentista, enredado no processo de intensificação das atividades econômicas, especialmente do comércio, fruto de mudanças que ampliaram a produção e a produtividade do trabalho agrícola europeu, bem como do expansionismo marítimo e da ampliação do processo de urbanização. No campo político, assistiu-se à crescente afirmação dos Estados Nacionais como agentes do poder, organizados, grosso modo, como monarquias absolutistas.

No campo intelectual - que aqui nos interessa de forma especial - transformações abrangentes ocorreram com a recuperação dos valores da Antiguidade. Em decorrência de tal fato, nos domínios das 
artes, tais como a literatura, escultura e pintura, observa-se a inspiração no passado greco-romano, inaugurando estéticas e sistemas de pensamento centrados no homem (EISENSTEIN, 1998). Entretanto, com relação à religião, os dogmas da Igreja Católica, em que pesem questionamentos mais intensos e, depois, a Reforma Protestante, ainda constituíam um poderoso eixo estruturante da vida social, especialmente nas penínsulas Ibérica e Itálica (THEODORO, 1991; EISENSTEIN, 1998; CERQUEIRA; LOPES, 1995;).

John Greville Agard Pocock (1975) destaca o fato de que, nos séculos XIV e XV, na região central e norte da Península Itálica ocorreu um renovado interesse, no que tange aos aspectos políticos, pela ideia da liberdade, inspirado nas cidades gregas - especialmente Atenas e Esparta - e em Roma. Centrais a essa ideia de liberdade eram os temas da igualdade dos cidadãos, assim como da virtude na arena pública. Aqui, destaque-se de pronto, a liberdade é vista como se realizando e sendo centrada no espaço público das cidades.

Contudo, é importante notar que a Península Itálica vivia, durante a Época Moderna, situação diferenciada em relação ao restante da Europa, no que tange à organização do poder e do Estado. Como destaca Adverse (2013, p. 54), “[as repúblicas italianas] encontram-se em uma situação inusitada: duas forças políticas com pretensões universalistas (o Império Sacro Romano-Germânico e a Igreja Católica) disputam a proeminência sobre o território italiano." Newton Bignotto também aponta para elementos conflituosos naquele momento:

O final do século XIV foi um momento muito especial da história italiana e em particular da história florentina. Em meio a guerras e ameaças de destruição e diante de uma onda de invasões estrangeiras, vários elementos de cultura, que estavam sendo gestados ao longo das décadas anteriores, encontraram sua maturidade e se constituíram sob a forma de um movimento intelectual original. (BIGNOTTO, 2001, p. 109)

Tendo por base a situação política na Península, de forma geral, e em Florença, de modo específico, formou-se uma nova corrente de pensamento: o humanismo cívico ${ }^{1}$, centrado no republicanismo, que se estabeleceu como rebento das tradições da Antiguidade greco-romana a partir da concretude política local. Nasceu, portanto, com os humanistas italianos, uma nova teoria sobre a vida pública, baseada em valores como autogoverno, liberdade de expressão, participação política e igualdade perante a lei.

O primeiro aspecto a ser destacado na visão dos pensadores renascentistas é a tensão entre a apologia de uma vida ativa e a de uma vida contemplativa. Por um lado, inspirados sobretudo em Aristóteles (384 a.C. - 322 a.C.) e Cícero (106 a.C. - 43 a.C.), havia aqueles que primavam pela defesa da vida política ativa. Por outro lado, filhos que eram da tradição cristã amparada em Agostinho de Hipona (354 - 430), muitos defendiam a vida contemplativa (BIGNOTTO, 2001).

\footnotetext{
${ }^{1}$ A origem da expressão humanismo cívico foi cunhada por Hans Baron, em A crise do Renascimento italiano (1966), texto no qual o autor propõe que houve uma ruptura entre o pensamento humanista italiano e o período medieval.
} 
Para além disto, outras questões levantadas pelos pensadores do período permitem delinear o que seria o núcleo central desse humanismo cívico: a valorização da ação no ambiente público; a virtude como base da vida humana, mas sustentada na polis, e um regime político que a estimulasse e a garantisse por meio da liberdade; o governo das leis, como esteio da liberdade e da igualdade, e a valorização da história como base de ancoragem do conhecimento (BIGNOTTO, 2001; ADVERSE, 2013).

Em fins do século XV, a Península Itálica vivenciou uma situação de grande tumulto político em consequência do ataque francês, liderado pelo rei Carlos VIII (1470-1498), com o objetivo de conquistar o Reino de Nápoles, no sul do território italiano. Destaca Bignotto (2006, p. 10):

O ano de 1494 é um marco importante no período [...]. Com a expulsão dos Médici de Florença e a ascensão de um governo com claras preocupações republicanas, iniciou-se uma série de debates dentro dos quais se insere uma boa parte dos principais textos políticos do começo do século XVI na Itália. Alguns, como O príncipe de Maquiavel, são bastante conhecidos, mas o que nos interessa ressaltar é o fato de que a tradição construída pelos chamados humanistas cívicos encontraria no final do quattrocento seus limites e passaria por transformações que mais uma vez fariam do pensamento republicano uma referência obrigatória nos debates políticos. Desses debates participaram tanto os defensores de uma república popular, que iriam manter suas posições até 1530, quando a república foi definitivamente extinta em Florença, [...], quanto escritores que, como Maquiavel, vinculavam seu republicanismo a uma leitura renovada da tradição política da Antiguidade.

Nicolau Maquiavel atuou como secretário da Segunda Chancelaria de Florença de 1498 até 1512. Foi a partir dessa experiência que construiu as bases do seu ideário republicano. Destaca José Guilherme Merquior (2014, p. 99):

O paradigma maquiavélico atribuiu primazia ao tempo. Antes de Maquiavel, a visão ocidental da política girava em torno de valores intemporais. Mesmo em Florença, as opiniões rivais de Guicciardini, o elitista, e Giannotti, o populista, procuravam ainda uma constituição imutável, equilibrada, um dique de ordem contra o mar da história. Maquiavel foi o primeiro a voltar-se ousadamente para a história, e não dela se afastar. Consciente do imprevisível interrelacionamento da fortuna e da coragem, fortuna e virtú, favoreceu a inovação política.

Três aspectos centrais, no que aqui nos interessa apontar, estruturam a obra do pensador florentino: a discussão entre conflito e liberdade, a disputa virtú e fortuna e, por fim, a estrutura de poder sobre a qual se organiza a estrutura política. Analisa Goyard-Fabre (2003, p. 103):

É certo que a obra do florentino coloca um problema de interpretação. Contudo, os seis primeiros capítulos do primeiro livro dos Discursos² são perfeitamente explícitos. A democracia, diz Maquiavel, fez a grandeza de Roma pois foi fonte de grande virtude; quando o povo deixou de participar dos assuntos públicos, começou o declínio; a queda era inevitável.

No que tange à questão da relação virtú-fortuna, o pensamento maquiaveliano operou uma tripla mudança. A primeira delas, ao perceber a interação entre os dois elementos como intensamente dinâmica; a segunda, ao caracterizar a virtude como ação criativa, que deve ser o motor do exercício do poder pelo

2 Goyard-Fabre (2003) refere-se à obra Discursos sobre a primeira década de Tito Livio, publicada pela primeira vez em 1532. 
governante, em oposição a certa postura passiva dos cidadãos; a terceira e última transformação foi trabalhar com a virtú não como algo permanente e dado, mas como a capacidade de adaptação às circunstâncias (SENELLART, 2006).

A equação virtú/fortuna, como experiência da relação do homem com o mundo, em Maquiavel é destacada por Hannah Arendt (2002, p. 182):

A virtú, por outro lado, que é segundo Maquiavel a qualidade humana especificamente
política, não possui a conotação de caráter moral da virtus romana, e tampouco a de
uma excelência moralmente neutra à maneira da areté grega. A virtú é a resposta que o
homem dá ao mundo, ou, antes, à constelação da fortuna em que o mundo se abre, se
apresenta e se oferece a ele, à sua virtú. Não há virtú sem fortuna e não há fortuna sem
virtú; a interação entre elas indica uma harmonia entre o homem e o mundo - agindo
um sobre o outro e realizando conjuntamente - tão remota da sabedoria do político
como da excelência moral (ou de outra espécie) do indivíduo e da competência dos
peritos.

Maquiavel foi um defensor da liberdade e considerava as disputas políticas como fonte de vitalidade para a república. Segundo ele, seriam as disputas que conduziriam à liberdade. Eram elas o motor da construção das leis e instituições republicanas:

Os que condenam as lutas entre os nobres e as plebes parecem desaprovar a causa
primeira que assegurou a liberdade de Roma, prestando mais atenção ao barulho e ao
clamor de tais tumultos, do que aos bons efeitos que deles resultam. Não percebem
que em qualquer república há duas diferentes disposições, a do povo e a dos
poderosos, e que todas as leis favoráveis à liberdade provêm de sua desunião
(MAQUIAVEL, 2007, p. 21-22).

Neste ponto é possível identificar uma ruptura de Maquiavel com o republicanismo clássico. Este reconhecia as divergências e disputas, mas as caracterizava como negativas. Para o florentino, no entanto, liberdade e lei eram frutos de um processo de disputa política. Logo, livre era a República capaz de construir instituições e leis para a solução das disputas (ADVERSE, 2013).

Quentin Skinner (1996) afirma que, apesar da dissonância no que diz respeito ao papel das disputas, um dos aspectos centrais do republicanismo, tanto o clássico quanto o do Renascimento, era a defesa do diálogo entre as diferentes partes como forma de se chegar à solução das disputas. O que coloca a divergência e a disputa como elementos centrais da esfera pública na sociedade.

De maneira geral, cabe destacar, como propõe Adverse (2013, p. 112):

Talvez, o republicanismo renascentista, em um período de 150 anos, tenha feito mais do que configurar um ideário político em que os termos "liberdade", "governo das leis", "vida cívica" e "participação política" desempenham um papel chave. A partir de sua crítica interna, permeável à realidade política em que brotou e se desenvolveu, o humanismo do Renascimento talvez tenha amadurecido, pela primeira vez no mundo ocidental, um projeto político republicano que será reestruturado, rearranjado e rearticulado nos séculos seguintes.

Os séculos seguintes assistiram à apropriação desse legado em diferentes articulações, em consonância com as novas condições concretas que caracterizaram a Modernidade. 


\section{REPUBLICANISMO E MODERNIDADE: OS INGLESES}

A análise historiográfica sobre o republicanismo inglês é bastante recente. Zera Fink (1962), Felix Raab (1965) e Pocock (1975) localizaram a presença do pensamento republicano na ilha e, a partir de suas obras, podemos reconhecer como as ideias e proposições de John Milton (1608-1674), James Harrington (1611-1677), Marchamont Nedham (1620-1678) e Algernon Sidney (1623-1683) construíram um conjunto de reflexões e respostas às questões políticas que se colocavam à Inglaterra do século XVII. Sobre os autores associados ao conceito de republicanismo moderno, salienta Barros (2013, p. 128):

Sob essa designação, foram relacionados autores que defenderam princípios e valores
republicanos a partir de diferentes perspectivas, propósitos e estilos. Embora
sustentassem concepções semelhantes não produziram manifestos nem trabalhos em
parceria. Por isso, [...], parece muito difícil identificar uma teoria sistemática entre
autores que partilharam muito mais uma linguagem do que uma doutrina. Mas é
possível encontrar nos seus escritos, [...] um quadro de preocupações, motivações e
soluções, que permite tratá-los conjuntamente, não como um grupo homogêneo de
autores, mas como os principais representantes de uma fase crucial do
republicanismo moderno.

Durante os séculos XVI e XVII, enquanto se difundiam o humanismo cívico e as ideias republicanas, inúmeras transformações e lutas ocorriam na Inglaterra. Conflitos sociais, disputas de poder, enfrentamentos religiosos e entre interesses econômicos, todos esses fenômenos confluíam para um período de grande agitação situado, grosso modo, entre 1625, data da ascensão ao poder de Carlos I (1600-1649), e a promulgação da Bill of Rights, em 1689 (ARRUDA,1996).

No âmbito rural, o processo de enclosures, o cercamento dos campos, colocou em situação difícil os trabalhadores rurais e serviu de estímulo a inúmeras revoltas camponesas, das quais participaram desde grupos mais moderados, como os levellers, até os mais radicais, como os diggers. Enquanto os primeiros defendiam propostas de caráter liberal, com garantias de liberdade e propriedade, os segundos agitavam a bandeira da tomada de terras. Também no âmbito urbano, a agitação se ampliou, com protestos de artesão que, vendo suas condições de trabalho e de vida piorarem, passaram a reclamar redução da jornada de trabalho e aumento de salários. Dissemina-se, portanto, um quadro de ampla dissensão e disputa entre os diversos grupos da sociedade inglesa (ARRUDA,1996; BEAUD, 2004).

Christopher Hill (1987) aprofundou a análise do quadro da revolução ou guerra civil inglesa. Para além das disputas entre anglicanos e católicos, de um lado, e presbiterianos, de outro, ou entre um parlamento liberal, representativo de grupos ligados aos interesses comerciais, e o absolutismo monárquico, vinculado aos interesses dos grandes proprietários de terra, o autor destaca a presença dos 
grupos populares com diversos interesses e visões de mundo - como os levellers ${ }^{3}$, diggers ${ }^{4}$ e pentamonarquistas ${ }^{5}$ - e de várias seitas - batistas, quacres, muggletonianos ${ }^{6}$, seekers ${ }^{7}$, anters. ${ }^{8}$

Por fim, nesse sumário quadro socioeconômico da revolução em curso, não podemos deixar de destacar o papel da gentry ${ }^{9}$, que foi uma força econômica, política e social nesse processo. Seus interesses em torno da defesa da propriedade e do livre comércio foram firmemente recepcionados ao final do século XVII, constituindo-se como a base de poder da monarquia que se estabeleceu a partir de então (ARRUDA, 1996).

Ao longo do século XVI, a discussão política na Inglaterra estava focada na questão da soberania. Quem podia dispor dos elementos fundamentais para o exercício do poder? Temas como a declaração de guerra e de paz, criação ou extinção de tributos, nomeação de funcionários, realização de julgamentos em instância final e, posteriormente, até o poder de legislar, estavam no centro do debate.

A disputa se intensificou com a ascensão dos Stuarts ao trono, no início do século XVII. ${ }^{10}$ Em 1603, com a morte de Elisabete I, sem herdeiros, assumiu o trono o rei Jaime Stuart, da Escócia. A Inglaterra, em que pese já contar com boa dose de centralização política a essa altura - diferentemente de boa parte da Europa continental - possuía, de acordo com Barros (2013) um rei que não tinha "exército permanente, autonomia financeira ou corpo de funcionários dependentes e fiéis à Coroa". Além disso, ainda de acordo com o autor, a Igreja Anglicana era incapaz de contentar os cristãos, pois ficava num meio-termo entre o catolicismo, e o protestantismo (BARROS, 2013, p. 130).

Tanto Jaime I (1603-1625) quanto, principalmente, seu filho e sucessor, Carlos I (1625-1649), tiveram inúmeras dificuldades com o Parlamento, especialmente pelo fato de que suas propostas de aumento e/ou criação de impostos foram sucessivas vezes recusadas, o que, via de regra, tinha como resposta a dissolução do Parlamento. Em 1640, depois de mais de uma década sem convocar o Parlamento, Carlos I foi obrigado a fazê-lo, diante da invasão de tropas escocesas à região norte da Inglaterra (BARROS, 2013).

3 Os levellers eram assim conhecidos por pretenderem nivelar as distintas condições sociais (HILL, 1987).

4 Os diggers, do verbo to dig, cavar, eram assim denominados por defender a ocupação de terras, em oposição aos poderes estatais (HILL, 1987).

5 Pentamonarquistas diz respeito ao movimento milenarista atuante em Londres e em outros pontos da Inglaterra, entre 1649 e 1661, que tinha como proposta reformular estruturas sociais, políticas, administrativas e jurídicas para que, assim, Cristo instalasse a Quinta Monarquia, período de mil anos de felicidade que antecederia o Juízo Final (HILL, 1987).

6 Muggletonianos, pequeno movimento cristão, com características apolíticas e pacifistas, surgido em Londres, em 1651, que não acreditava nas práticas de adoração e pregação (HILL, 1987).

7 Seekers, seita calvinista inglesa que defendia o fim da hierarquia social, da propriedade privada e do casamento monogâmico e acreditava na predestinação da salvação dos eleitos. Defendiam, ainda, a ação direta, violenta, se preciso, para conquistar seus objetivos (HILL, 1987).

8 Ranters, seita calvinista inglesa que defendia o fim da hierarquia social, da propriedade privada e do casamento monogâmico e acreditavam na predestinação da salvação dos eleitos. Diferentemente dos seekers, não defendiam a ação direta. (HILL, 1987)

9 O termo gentry cobria um grupo de homens que tinham todos as mesmas relações com os meios de produções: eram proprietários de terra não arrendada e produziam para o mercado. Trata-se de uma classe capitalista emergente que foi recrutada a partir de variadas categorias sociais (WALLERSTEIN apud ARRUDA, 1996, p. 54).

10 Os Stuarts foram os primeiros reis do Reino Unido. Governaram Inglaterra, Escócia e Irlanda, com as intermitências ocasionadas pelas revoluções inglesas do século XVII. Entre 1603 e 1714 foram substituídos pela Dinastia de Hanôver. 
A situação parecia incontornável para o rei. Uma nova crise, no entanto, veio a maximizar o confronto entre Carlos I e o Parlamento. Desta feita, houve a necessidade de convocar um exército para reprimir uma rebelião de católicos na Irlanda. Instalou-se uma disputa sobre quem deveria comandar essas tropas. O rei exigia que fosse ele, mas o Parlamento estava temeroso que as tropas fossem usadas contra si. Carlos I - depois da aprovação de resolução contrária aos interesses reais sobre a questão pela Câmara dos Comuns - exigiu que os propositores do texto fossem presos. Sem apoio parlamentar, o rei deixou Londres e dirigiu-se à cidade de Oxford, onde se instalou com a Corte. Em agosto de 1642, começou a Guerra Civil que, com muitas idas e vindas, resultou na prisão, julgamento, condenação e execução do rei, em 30 de janeiro de 1649. Em 19 de maio este ano, foi criada a Commonwealth of England, denominada de Estado livre, na prática uma república (HILL, 1987; ARRUDA, 1996; BARROS, 2013). Sobre o processo de desenvolvimento e disseminação das ideias republicanas na Inglaterra, afirma Barros (2013, p. 128):

Na Inglaterra, seus primeiros sinais só podem ser observados no decorrer do século
XVI, com a propagação dos valores humanistas. Manifestou-se de forma um pouco
mais clara nas primeiras décadas do século XVII, no interior do movimento de
protesto contra o reinado dos Stuarts, e, posteriormente, de modo evidente, no
desenrolar das guerras civis. Mas sua plena expressão deu-se apenas depois do
regicídio, em 1649, o que tem levado muitos historiadores a considerar que o
republicanismo inglês foi muito mais consequência do que causa do fim da
Monarquia.

Podemos, portanto, perceber um quadro - ainda que apontado com brevidade - marcado por tensão, disputa, rivalidade e diversidade. Em meio a esse processo intenso é que se desenvolveram as ideias republicanas inglesas. Um dos aspectos importantes para a difusão de tais ideais foi a questão do direito de resistência à tirania. Neste aspecto, encontrava-se como questão de fundo a ideia do pacto social. A legitimidade de um governante só era garantida na medida em que este conduzia os negócios públicos com base no interesse comum. Destaque-se, ainda, o fato de que, em tese, a soberania popular não havia sido alienada para o monarca, mas apenas a ele delegada a título provisório; uma vez que o contrato social deixava de ser cumprido, essa soberania podia e devia ser retomada (BARROS, 2013).

Milton, um dos mais destacados republicanistas ingleses do período, entendia a questão desta maneira, até de forma ainda mais radical. Barros aponta quatro consequências centrais desta visão:

Não há submissão natural nem senhorio estabelecido pela natureza; o título dos reis e dos magistrados não pode ser hereditário, uma vez que a autoridade do povo não é transferida definitivamente, mas meramente delegada, não tendo o governante a propriedade do poder político; se o rei for considerado apenas responsável perante Deus, como sustentavam os realistas, todos os pactos celebrados com ele durante a coroação, todos os juramentos feitos por ele de respeitar as leis do reino, seriam vãos; o povo, por ser a origem da autoridade do rei, pode sempre que considerar adequado, rejeitá-lo e removê-lo, mesmo que não seja um tirano, pela simples razão de ter a liberdade e o direito de fazê-lo quando considerar conveniente (BARROS, 2013, p. 143). 
Para Milton, a garantia da liberdade política seria o governo das leis. Só esse governo poderia impedir o abuso de poder por parte de uns ou a submissão ao poder por parte de outros. Logo, todos os membros de uma sociedade, ainda mais os reis e magistrados, estavam submetidos à lei. Contudo, os republicanistas como Milton, Sidney, Nedham e Harrington, quando colocavam a questão da liberdade, não estavam discutindo a liberdade individual. Analisa Skinner (1996, p. 30-31):

A teoria da liberdade que eles esposam me parece constituir o cerne do que é específico em seu pensamento. Mais do que seu às vezes ambíguo republicanismo, mais até do que seu inquestionável compromisso com uma política de virtude, sua análise da liberdade civil assinala-os como os protagonistas de uma ideologia específica, e mesmo como uma única escola de pensamento. [...]. Eles começam assim por enfocar não a liberdade de indivíduos, mas sim o que Milton denomina "liberdade comum" ou "governo livre", o que Harrington denomina "a liberdade de uma comunidade", e o que Sidney mais tarde chama de "as Liberdades de Nações". Como o título de Nedham ressonantemente nos lembra, a principal aspiração de todos esses autores era vindicar "a excelência de um Estado livre".

Os indivíduos são livres apenas enquanto seres capazes de tomar uma decisão e agir de acordo ou a ela se negar. Nesta perspectiva, os referidos autores defendiam que um Estado só seria livre na medida em que as decisões fossem tomadas pelo conjunto de seus membros. Há uma ligação bastante clara com o pensamento maquiaveliano dos Discursos, nos quais o pensador florentino afirma que as cidades livres eram aquelas governadas por sua própria decisão (SKINNER, 1996).

Milton, em especial, associava a liberdade do povo e a responsabilidade do governo com a liberdade de imprensa. Afirma Keane (2010, p. 239-240):

Poderosa e persuasivamente, [...], o manifesto em prosa de Milton, a Aeropagítica, de fato reuniu os vários fios de prata do governo representativo, depois os amarrou com o laço dourado da liberdade de imprensa. Ele favoreceu o governo republicano através de assembleias parlamentares [...]. Milton estava confiante de que a imprensa podia ser usada para garantir que os representantes não saíssem da linha ou que se eles caíssem [...] seus enganos e falso orgulho podiam ser expostos por impresso, para um público leitor que tinha opiniões sobre como desejava ser governado.

Milton, Nedham e Harrington, em suas obras, foram incisivos defensores da república. ${ }^{11}$ Para eles, só a república, sendo o governo do povo, garantiria liberdade, evitando a tirania e a corrupção. Isto permitiria que o interesse comum fosse predominante, garantindo a estabilidade e evitando os tumultos, frutos de privilégios ou abusos de poder (BARROS, 2013).

A obra fundamental do republicanismo inglês, no entanto, é Discourses concerning government, de Algernon Sidney. O autor, no entanto, a deixou incompleta por conta de sua prisão, condenação e execução, em 1683. A obra só viria a ser publicada em 1698. Nos Discourses, o autor ataca, de forma direta, a tirania dos Stuarts, destacando que o arbítrio real colocava todos em situação de servidão, garantindo-se, assim, o direito à resistência. Afirma, ainda, a soberania do povo na escolha do governante,

\footnotetext{
11 Aqui, estamos nos referindo especialmente a The tenure of kings and magistrates, de 1649, e Pro populo anglicano defensio, de 1651, de John Milton; The case of the Commonwealth of England, Stated, de 1651, e The Excellency of a Free State, de 1656, de Marchmont Nedham; e Commonwealth of Oceana, de 1656, de James Harrington.
} 
destacando que estes estavam, como qualquer magistrado, submetidos às leis, sendo estas a forma por excelência de se sustentar o bem comum. Desta forma, a função básica do governo seria assegurar a vida, a liberdade e a propriedade. Ademais, Sidney salienta que as magistraturas deveriam ser acessíveis aos mais virtuosos cidadãos, e, por fim, ressalta que somente as repúblicas eram qualificadas para realizar todo esse projeto (BARROS, 2013).

Assim, sobre o republicanismo inglês, Barros conclui:

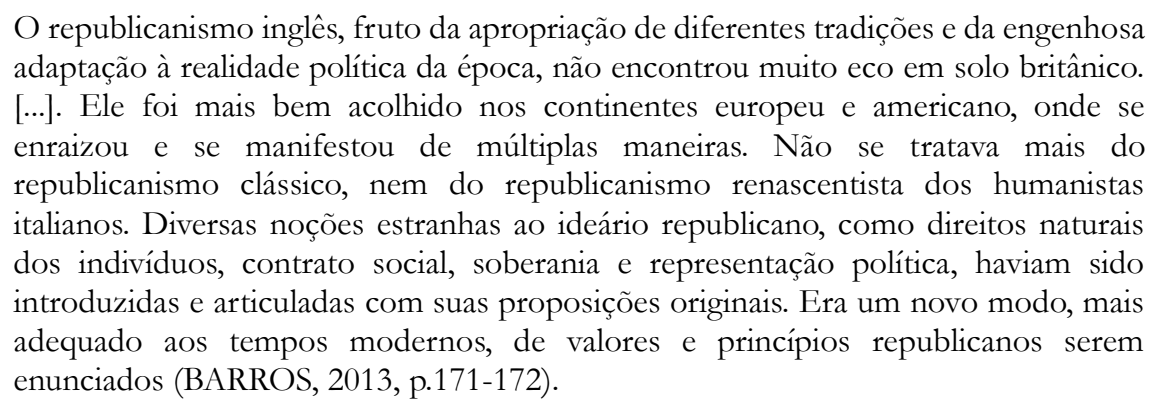

Por certo, a trajetória do republicanismo ganhou novos elementos constituintes e, em que pese seu fracasso na Inglaterra, teve frutíferas repercussões no restante da Europa, espalhando-se principalmente a partir da França, bem nas 13 colônias inglesas da América.

\section{REPUBLICANISMO E MODERNIDADE: OS FRANCESES}

O republicanismo francês, por certo, é dos mais impactantes da história contemporânea. Os eventos marcantes da história da versão francesa do republicanismo são, obviamente, a Revolução de 1789 e seus desdobramentos. Mas seria algo injusto, com tão rica tradição, apontar somente aqueles como momentos de fundação ou, até mesmo, de afirmação dessa matriz. Por mais que a Revolução tenha tido papel significativo para o desenrolar de ideias e experiências desse campo, foram necessários, pelo menos, cerca de dois séculos para afirmar essa escola do pensamento republicano: os séculos XVIII e XIX. Como destaca Bignotto (2013, p. 176), “a experiência republicana só encontrará uma forma estável de governo quase um século depois, por ocasião da implantação da Terceira República, já na década de 1870."

No entanto, as origens dessa vertente do republicanismo situam-se no século XVIII, como aponta o filósofo Nilo Odalia (2003, p. 159-161):

O século XVIII [...] dá início ao processo de construção do homem comum como sujeito de direitos civis. [...]. A Revolução Francesa como fundadora dos direitos civis impõe que não nos esqueçamos que o século XVIII é conhecido como o século do Iluminismo e da Ilustração. [...]. Nele se deu, também, a tentativa de transformar as ciências da natureza em ciências da razão e da experimentação. [...] Razão e experimentação se aliavam no que, então, se acreditava ser o verdadeiro caminho para o estabelecimento do conhecimento científico. [...]. É ainda no século XVIII que o homem começa a tomar consciência de sua situação na história, [...] que a ideia de felicidade nasce, não como uma conquista individual, mas como uma meta a ser alcançada pela coletividade. [...]. Uma sociedade justa, para os intelectuais do século 
XVIII, é aquela em que as leis e o direito sejam naturais, ou seja, nasçam com o próprio homem. É, portanto, nesse século que irá ser consolidada uma nova teoria do direito, o direito natural, em oposição ao chamado direito positivo ou histórico.

Já o historiador Eric Hobsbawm (2000, p. 71-72) põe o foco sobre o impacto do movimento revolucionário francês:

\begin{abstract}
Se a economia do mundo do século XIX foi formada principalmente sob a influência da revolução industrial britânica, sua política e ideologia foram formadas fundamentalmente pela Revolução Francesa. [...]. Foi a França que fez suas revoluções e a elas deu suas ideias [...] e a política europeia (ou mesmo mundial) entre 1789 e 1917 foi em grande parte a luta a favor e contra os princípios de 1789, ou os ainda mais incendiários de 1793. [...]. A Revolução Francesa pode não ter sido um fenômeno social isolado, mas foi muito mais fundamental do que os outros fenômenos contemporâneos e suas consequências foram, portanto, mais profundas. [...], ela foi, diferentemente de todas as revoluções que a precederam e a seguiram, uma revolução social de massa, e incomensuravelmente mais radical do que qualquer levante comparável.
\end{abstract}

A Revolução Francesa colocou por terra a legitimidade política da estrutura hierarquizada do Antigo Regime, colocando, assim, a necessidade de o Estado garantir aos indivíduos a sua liberdade, assegurando-lhes direitos. Afirmou, por um lado, o papel das instituições, mesmo que politicamente voláteis, mas, por outro, tensionou a relação entre os entes estatais e os cidadãos (MERQUIOR, 2014).

Apesar de ter acelerado o processo de mudanças, a revolução não foi, contudo, o seu agente inicial. Tocqueville já destacava que ela foi o apogeu do desenrolar de transformações que já se operavam na sociedade francesa (ODALIA, 2003). Seus impactos são, por certo, internacionais. Já em seu primeiro documento fundamental, a Declaração dos Direitos do Homem e do Cidadão, fica evidente o seu apelo universalista, que busca garantias fundamentais aos homens, sejam de onde for e sem qualquer distinção. ${ }^{12}$ Destaca Odalia (2003, p. 164): “É uma declaração que pretende alcançar a humanidade como um todo. É universal e por isso sensibiliza a seus beneficiados e faz tremer, em contrapartida, em toda a Europa, as monarquias que circundavam a França.” O historiador Marco Mondaini caminha no mesmo diapasão:

Entre o estouro revolucionário, em julho de 1789, e a declaração de guerra à Áustria, em abril de 1792, a revolução deixa progressivamente de ser apenas francesa em virtude da forte expansão de movimentos inspirados pelos ideais revolucionários de liberdade, igualdade e fraternidade por toda a Europa. A luta contra a série quase interminável de privilégios de príncipes, senhores feudais e bispos alastra-se a ponto de se poder falar de uma revolução da Europa Ocidental. (MONDAINI, 2007, p. 194).

Nesse processo de transformação - francês, e aos poucos, também europeu - a ordem política foi totalmente modificada. A noção de soberania real foi abolida e substituída pela soberania do povo (MONDAINI, 2007). O processo político revolucionário, entretanto, manteve uma tradição de unicidade

\footnotetext{
12 Por certo, as mulheres estavam excluídas desses direitos. Isso levou a uma rápida reação de setores das revolucionárias francesas. Já em 1791, Olympe de Gouges produziu a Declaração dos Direitos da Mulher e da Cidadã, sobre a qual salienta a historiadora Flávia Lages de Castro (2013, p. 254): "Esta declaração, um marco qualitativo na história das ideias de igualdade."
} 
herdada do Antigo Regime, e, essa, por sua vez, se fará presente na matriz republicana francesa. Como aponta o historiador Roger Osborne (2013, p. 173-174):

A aplicação de um modo particular de entendimento da política revolucionária indicava que havia apenas uma forma possível de governo verdadeiro - qualquer outro caminho era visto como traição, uma traição à Revolução e ao povo da França. [...] A crença num único caminho, o uso do terror contra adversários políticos, a ilegitimidade de qualquer forma de oposição, o pressuposto de agir "em nome do povo" [...]. Por outro lado, a França deu a seu povo direitos políticos e liberdades que estavam além até mesmo dos que tinham os cidadãos dos recém-fundados Estados Unidos.

Não há, entretanto, como por vezes se tem tentado identificar, uma contradição entre esses dois elementos de tensão apontados. O sociólogo José Guilherme Merquior destaca que muitas das reformas empreendidas na Europa por monarcas vinculados ao ideário iluminista, como o imperador José II da Áustria, não eram liberais na sua forma de execução, mesmo apresentando "uma perspectiva genuína de emancipação para camponeses e protestantes, judeus e o homem do povo. [...]. Mesmo quando não era liberal, o Iluminismo terminava por desbravar terreno para instituições mais livres e [...] uma sociedade menos desigual.” (MERQUIROR, 2014, p. 88). Assim, não há como esperar uma suposta pureza das práticas políticas em processos de múltiplas interações, envolvendo setores sociais diversos. Em tal configuração, as ideias e práticas, obviamente, ganham múltiplas interpretações.

A questão que se colocava, em fins do século XVIII, fosse na América do norte, onde os colonos buscavam a independência com relação à Inglaterra, fosse na França, ou até mesmo em outros lugares da Europa, ia, como destaca Arendt (2011), para além de aspectos das liberdades civis, que muitos pessoalmente possuíam. Tratava-se de tornar visível aquilo que não o era: a existência de uma esfera pública, o espaço público, ou como destaca Arendt (2011, p. 170), “a ideia central da revolução, que é a fundação da liberdade, isto é, a fundação de um corpo político que garante o espaço onde a liberdade pode aparecer."

Bignotto (2013), por sua vez, destaca como a matriz republicana francesa tem como marca central a unicidade e indivisibilidade da nação. Neste sentido, qualquer manifestação de diferença era encarada como um risco para a sua permanência e continuidade, devendo, portanto, em nome do povo, ser combatida. Não obstante, a política revolucionária francesa de fins do século XVIII erigirá duas diferentes visões sobre a construção republicana.

De um lado teremos o ideário girondino e de outro o pensamento jacobino. O primeiro teve como marcas centrais o reconhecimento dos direitos individuais e da liberdade dos negócios, do papel das instituições jurídicas e do Direito. De matiz constitucionalista, portanto, essa matriz de pensamento flertava com o pensamento federalista norte-americano e com o liberalismo. O outro está assentado em uma posição consistentemente antifederalista, que sustentava a necessidade de unidade do corpo político, e que se amparava na defesa do interesse público acima dos individuais (HOBSBAWM, 2000; BIGNOTTO, 2013). 
No que aqui nos interessa, analisemos, primeiramente, o aspecto central do pensamento de Montesquieu. Este se encontra na sua tipologia do governo, quando caracteriza a República como o regime de governo cuja soberania está no povo e que tem como princípio a virtude. Por oposição, na monarquia o poder está nas mãos do rei, sendo regida pela honra; no despotismo, o governo é liderado por um tirano e tem como princípio de governo o medo. Destaca o filósofo José Augusto Guilhon Albuquerque (2000, p. 117):

Só a virtude é uma paixão propriamente política: ela nada mais é do que o espírito cívico, a supremacia do bem público sobre os interesses particulares. É por isso que a virtude é o princípio da república. Onde não há leis fixas nem poderes intermediários [...] somente a prevalência do interesse público poderia moderar o poder e impedir a anarquia ou o despotismo.

Sobre a soberania popular no governo republicano, podemos destacar as palavras de Montesquieu (2007, p. 23-24) quando este, além de distinguir entre uma república democrática e uma república aristocrática, já aponta para aspectos do que será a democracia representativa:

Quando, em uma república, o povo, formando um só corpo, tem o poder soberano, isso vem a ser uma democracia. Quando o poder soberano está nas mãos de uma parte do povo, trata-se de uma aristocracia. O povo, na democracia, é, em certos aspectos, o monarca, e, em outros aspectos, o súdito. $\mathrm{O}$ povo somente poderá ser monarca pelos sufrágios, os quais constituem suas vontades. A vontade do soberano é o próprio soberano. [...]. O povo, quando tem o poder soberano, deve fazer por si mesmo tudo aquilo que possa fazer corretamente; e tudo o que não puder fazer corretamente, cumpre que o faça por intermédio de seus ministros.

Sob tal raciocínio, a virtude, que destaca o interesse público como superior ao privado, e a soberania popular, como um governo assente na vontade do povo, são dois dos elementos centrais que o republicanismo francês, bebendo das fontes históricas de sua tradição, irá encontrar em Montesquieu. Estas duas ideias serão fortemente enfatizadas no processo revolucionário em fins do século XVIII e adiante.

Do pensamento de Rousseau, também presente nas diversas correntes do republicanismo francês e nas visões políticas de inúmeros de seus líderes, as principais temáticas apropriadas pela tradição francesa são: a questão da virtude, especialmente a cívica, a liberdade, o interesse público e a vontade geral (BIGNOTTO, 2013). O filósofo Milton Meira do Nascimento (2000, p. 196) destaca do pensamento de Rousseau:

Obedecer a lei que se prescreve a si mesmo é um ato de liberdade. [...]. Um povo, portanto, só será livre quando tiver todas as condições de elaborar suas leis num clima de igualdade, de tal modo que a obediência a essas mesmas leis signifique, na verdade, uma submissão à deliberação de si mesmo e de cada cidadão, como partes do poder soberano. Isto é, uma submissão à vontade geral e não à vontade de um indivíduo em particular ou de um grupo de indivíduos. Tal é a condição primeira de legitimidade da vida política. 
A vontade geral não é, portanto, o extermínio do indivíduo, e sim a percepção daquelas direções comuns preponderantes no corpo político - ou seja, no conjunto dos indivíduos - para fazê-las avançar. Em Rousseau, a obra que melhor representa seus princípios republicanos, é Do contrato social, no qual o autor explicita:

Só a vontade geral pode dirigir as forças do Estado segundo o fim de sua instituição, o bem comum, pois, se a discordância dos interesses particulares tornou necessária a fundação das sociedades, a harmonia desses interesses a possibilitou. Eis o que há de comum nos diversos interesses que formam o laço social, e não existiria sociedade alguma se não houvesse ponto em que os interesses concordassem. Ora, é somente nesse comum interesse que deve ser governada a sociedade. Digo, portanto, que não sendo a soberania mais que o exercício da vontade geral, não pode nunca alienar-se; e o soberano, que é unicamente um ser coletivo, só por si mesmo se pode representar. É dado transmitir o poder, não a vontade (ROUSSEAU, 2007, p. 36).

Apesar de todas as tensões e contradições que se desdobraram ao longo do processo revolucionário e nos períodos subsequentes até a definitiva afirmação da República francesa, em 1870, inúmeros elementos da matriz republicana foram deixados como legado para a tradição política daquele país e do Ocidente, de maneira mais ampla. Explica Cardoso (2013, p. 220):

Podemos destacar pelo menos três questões que farão parte do repertório de debates de todos os que de uma maneira ou de outra se aproximaram da matriz republicana do século XVIII na primeira metade do século seguinte. O primeiro deles era a questão da unidade da república. [...]. Um segundo tema que aparece com frequência é o sufrágio universal. [...]. Por fim, a questão do papel da burocracia será relevante para retirar o debate sobre o republicanismo de seu molde original e conduzi-lo ao terreno dos problemas afeitos às práticas de governo.

Nesse mesmo momento histórico desenvolvia-se, também em condições de revolução, uma outra - e diversa - matriz do republicanismo, a norte-americana, que agora abordaremos.

\section{REPUBLICANISMO E MODERNIDADE: A MATRIZ NORTE-AMERICANA}

Ao longo do período que vai do início da década de 1760 até a promulgação da Constituição dos Estados Unidos da América, em 1787, e da chamada Carta de Direitos ${ }^{13}$, de 1791, será construída a base da matriz norte-americana do republicanismo. Ela foi o fruto mais radical do processo de rebelião e revolução nas treze colônias contra o domínio inglês (STARLING, 2013).

Segundo o historiador Bernard Bailyn (2003), com o fim do período conhecido como negligência salutar ${ }^{14}$ por parte da Inglaterra - que irá ocorrer após o fim da Guerra dos Sete Anos (1756-

13 Conjunto de 10 emendas à Constituição dos Estados Unidos da América que garantiu uma série de direitos civis e liberdades individuais. Inspirada na Bill of Rights inglesa, de 1689, foi adotada por pressão dos antifederalistas para aceitar a criação de um governo central fortalecido pela Constituição dos EUA (KARNAL et al., 2007).

14 A política de negligência salutar foi adotada pela Inglaterra em relação às treze colônias norte-americanas a partir de início do século XVII. Ela consistia basicamente em conceder um alto grau de liberdade política, administrativa e econômica às treze colônias. Para além de outras questões, a principal causa apontada para a sua adoção foram as próprias dificuldades internas inglesas ao longo de boa parte do século XVII, no período compreendido entre a ascensão de Carlos I, em 1625, e a Revolução Gloriosa, em 1689. Mas, após isso, a luta política continuará devido às inúmeras guerras em que a Inglaterra irá se envolver, principalmente com a França, mas também com a Espanha e a Holanda, entre outros países, muitas das 
1763) $)^{15}$ - os colonos norte-americanos começaram um processo de resistência que, a partir de 1775, iria se transformar em ação ofensiva para garantir suas liberdades e, por fim, a independência.

Foram múltiplas as influências ideológicas que os colonos receberam e, podemos dizer, reconstruíram, ao longo de suas lutas contra as autoridades e as tropas britânicas. Por certo, eles conheciam o pensamento puritano do Covenant ${ }^{16}$, como também as ideias do direito consuetudinário, ou da Commom Law ${ }^{17}$ inglesa, do contrato social de John Locke (1632-1704) e do direito natural iluminista. Estas ideias perpassaram as propostas e pensamentos dos colonos rebeldes, mas foram pensadores ingleses do fim do século XVII e início do XVIII que mais influenciaram esses revolucionários (BAILYN, 2003). Tais autores, por sua vez, tinham a sua ideologia formada por outros pensadores daquele país, pessoas que vivenciaram todos os percalços das lutas internas da Inglaterra no século XVII. Destaca Bailyn (2003, p. 50-51):

Entre os progenitores do século 17, dessa linha de escritores radicais do século 18 e políticos de oposição unidos na crítica ao poder ministerial e à “corte”, [John] Milton foi uma figura importante - não Milton o poeta tanto quanto Milton o publicista radical, autor de Eikonoklastes e The tenure of kings and magistrates (ambos publicados em 1649). Os escritores revolucionários norte-americanos referiam-se com igual respeito, ainda que com uma compreensão menor, à escrita mais sistemática de [James] Harrington e à de Henry Neville de ideias semelhantes; sobretudo referiamse às doutrinas de Algernon Sidney, aquele "mártir da liberdade civil", cujos Discourses concerning government (1698) tornaram-se, na expressão de Caroline Robbins, um "livrotexto da revolução" na América.

A ligação, portanto, com o republicanismo inglês fica evidente. Este, no entanto, não era um mero pastiche, uma cópia para simular as condições análogas de repressão e corrupção que tanto os colonos norte-americanos da segunda metade do século XVIII, quanto seus predecessores ingleses do século XVII e início do XVIII identificavam. Os primeiros, na Inglaterra, no rei e no Parlamento, de um modo geral; os segundos, na Corte e seus ministros de modo específico. Destaca a historiadora Heloísa Maria Murgel Starling (2013, p. 231):

Entre 1763 e 1791, as ideias foram reformuladas, surgiram proposições inéditas e o vocabulário do mundo público teve de ser redefinido para dar conta de uma nova configuração do pensamento que brotou no território da antiga América inglesa. No interior da matriz do republicanismo norte-americano, coube construir, por exemplo, a noção de que os direitos constituem uma condição de proteção do indivíduo e representam uma conquista histórica e política; ou de que a ideia de que os interesses possuem um papel agregativo e sua preservação também está atada à própria definição de liberdade; ou, ainda, a convicção de que a república pode ser erguida em um território de extensão continental e sua estrutura institucional sustentar-se em um

quais também se desenrolaram em território colonial (HUBERMAN, 1983; KARNAL et al., 2007).

15 A Guerra dos Sete Anos foi disputada, principalmente, entre a Inglaterra e a França, no período de 1756 a 1763. Na América do Norte, foi denominada de Guerra Franco-Índia. Vencida pela Inglaterra, implicou na virtual eliminação da presença francesa na região, pois os franceses tiveram que entregar para a Inglaterra, entre outros territórios, parte de suas possessões no Caribe e no Canadá (KARNAL et al., 2007).

16 O Covenant ou contrato entre Deus e os eleitos era central na visão de mundo, política, social e religiosa dos puritanos que tinham emigrado para as colônias ao longo dos séculos XVII e XVIII (BAILYN, 2003).

17 Lei ou Direito Comum, na tradução literal. Sistema de direito adotado predominantemente nos países de língua inglesa, sendo "um direito forjado por precedentes e não por legislações estabelecidas por legisladores especificamente" (CASTRO, 2013, p. 197). 
governo nacional forte, mas, ao mesmo tempo, limitado pela tarefa de preservar as liberdades de um Estado republicano.

Esse processo é decorrente das novas condições que a Inglaterra impôs às suas colônias, a partir de 1763, mas também de situações peculiares da cultura sociopolítica que os colonos construíram nos territórios norte-americanos desde o século XVII. Os conflitos entre os colonos e a Inglaterra começaram ainda no ano de 1763. Interessados em expandir o território colonial para as áreas entre os montes Apalaches e as terras até o rio Mississipi os norte-americanos entraram em conflito com os indígenas. A vitória, ao final, foi inglesa, mas a custo de muita luta e destruição. Para amenizar a situação, o rei Jorge III (1738-1820) proibiu aos colonos a ocupação de grande parte das terras pretendidas por eles, mas não só isso. A partir do ano seguinte, a situação iria se tornar, progressivamente, mais difícil: na relação entre as colônias e a sua metrópole, a negligência salutar acabara; agora, os mecanismos de dominação econômica, com forte viés mercantilista, estavam no topo da agenda britânica (KARNAL et al., 2007).

Em 1764, o governo inglês impôs três leis às colônias: a do Açúcar, a da Moeda e a da Hospedagem. Seus objetivos eram bastante claros: aumentar o controle e as receitas e diminuir os custos para a Inglaterra. No ano seguinte, mais uma lei, desta feita a Lei do Selo. A reação começa a se fazer sentir de forma organizada. Das treze colônias, nove enviaram representantes a um Congresso da Lei do Selo, no qual foi aprovada a Declaração dos Direitos e Reivindicações, documento que, apesar de reafirmar a lealdade ao rei, proclamava o princípio do No taxation without representation. ${ }^{18}$ A Lei do Selo foi revogada em 1766 mas, no ano seguinte, os Atos Townshend irão, novamente, tensionar a situação. Em 1770, ocorreu o chamado Massacre de Boston, com a morte de cinco colonos, enquanto seis outros ficaram feridos por ação de tropas inglesas. No ano de 1773, o monopólio da venda do chá pela Companhia das Índias Orientais foi imposto às colônias, o que gerou a reação que ficou conhecida como a Boston Tea Party. Como resultado, vieram as chamadas Leis Intoleráveis que, entre outras coisas, determinaram a interdição do Porto de Boston até o pagamento dos danos causados, transformaram Massachusetts em colônia real e restringiram o direito de reunião (HUBERMAN, 1983; KARNAL et al., 2007; WOOD, 2013).

A situação caminha num crescendo de ação e reação. Ao longo do tempo, as medidas britânicas foram, paulatinamente, enfrentando maior e mais obstinada oposição dos colonos, que geravam, por sua vez, novas iniciativas metropolitanas. Em 1774, reuniu-se o Primeiro Congresso Continental. Este aprovou documento dirigido ao rei inglês. O documento solicitava a revisão de todas as medidas tomadas, mas ainda sem se manifestar pela separação. No ano seguinte, a partir de 10 de maio, reúne-se o Segundo Congresso Continental que, diante da persistente recusa inglesa e do crescente sentimento separatista,

18 Nenhuma taxação sem representação. A ideia de que impostos só seriam válidos se contassem no seu processo de discussão/aprovação com a participação de representantes daqueles que iriam pagar. Essa é uma questão que remonta à Carta Magna, de 1215, e às lutas contra os Stuarts, no século XVII, na própria Inglaterra (KARNAL et al., 2007) 
acabou, finalmente, em 4 de julho de 1776, por aprovar a Declaração de Independência dos Estados Unidos da América (HUBERMAN, 1983; KARNAL et al., 2007; WOOD, 2013).

A retomada do processo separatista nos faz perceber que a participação em assuntos públicos e a associação para atividades coletivas esteve presente de forma marcante em todo o seu desenrolar. Sobre este aspecto, Tocqueville já diagnosticara, em meados do século XIX, o intenso espírito associativo dos norte-americanos: 'Independentemente das associações permanentes, criadas pela lei, sob o nome de comunas, cidades e condados, existe uma multidão de outras que só devem o seu nascimento e o seu desenvolvimento a vontades individuais" (TOCQUEVILLE, 1977, p. 146). O autor ressalta a amplitude desse universo organizativo:

\begin{abstract}
Os americanos de todas as idades, de todas as condições, de todos os espíritos, estão constantemente a se unir. Não só possuem associações comerciais e industriais, nas quais todos tomam parte, como ainda existem mil outras espécies: religiosas, morais, graves, fúteis, muito gerais e muito particulares, imensas e muito pequenas; os americanos associam-se para dar festas, fundar seminários, construir hotéis, edificar igrejas, distribuir livros, enviar missionários aos antípodas, assim também criam hospitais, prisões, escolas. Trata-se, enfim, de trazer à luz ou se desenvolver um sentimento pelo apoio de um grande exemplo, eles se associam (TOCQUEVILLE, 1977, p. 391-392).
\end{abstract}

Também Arendt destaca esse espírito participativo americano:

A questão é que os americanos sabiam que a liberdade pública consistia em participar de assuntos públicos e que as atividades ligadas a esses assuntos não constituíam de maneira alguma um fardo; ao contrário, proporcionavam aos que se encarregavam delas um sentimento de felicidade que não encontrariam em nenhum outro lugar (ARENDT, p. 163).

Os colonos foram desenvolvendo ideias do direito de resistência ao poder, da liberdade como elemento central da vida coletiva, mas, também, e, principalmente, das formas associativas como estratégias de proteção ao indivíduo, da importância da pública expressão dos interesses. Assim, de maneira bastante destacada, utilizavam e ampliavam a sua experiência de associativismo comunitário, que contribuiria para o processo de formação política dos colonos, para a comunicação entre os cidadãos e os seus diversos grupos e cidades e de base para a resistência que se organizava e continuamente se ampliava. Estas, portanto, são as características centrais da matriz norte-americana do republicanismo (BAILYN, 2003; KARNAL, 2003; KARNAL et al., 2007; STARLING, 2013; WOOD, 2013).

\title{
CONSIDERAÇÕES FINAIS
}

A partir desta exposição sumária das principais matrizes do republicanismo na modernidade, apontamos elementos de sua formação histórica, seus principais pensadores e sua presença e participação em processos históricos específicos, mas centrais. Cumpre-nos, agora, apontar alguns elementos decisivos dessa tradição, não necessariamente comuns a todas, mas que revelam um certo conjunto 
homogêneo de preocupações e ideários. Este nos permite definir traços de uma dada tradição política republicana, cujas temáticas encontram-se enredadas nas questões políticas candentes da atualidade.

Uma questão, por óbvia, mas significativa, que inicialmente destacamos é o repúdio comum à monarquia até então definida como a mais adequada forma de governo para os Estados nacionais que se formaram desde o século XV. Ingleses e franceses levaram isso até o ponto de condenarem os seus monarcas à morte: Carlos I, na Inglaterra, e Luís XVI, na França. Os norte-americanos, por repudiar a possibilidade de, a partir de sua independência, construir uma monarquia em suas terras (GELDEREN; SKINNER, 2002). Sobre este aspecto, é interessante notar que, na Europa ocidental, misturadas às questões envolvendo identidades étnicas regionais, demandas de movimentos separatistas, de caráter republicano, ainda se arrastam até os dias de hoje no interior de Estados nacionais monárquicos.

Um segundo aspecto a ser destacado, no âmbito das heranças do republicanismo, é a importância da questão da liberdade, expressão aqui entendida em ao menos três de suas possibilidades: liberdade negativa, como ausência de opressão; liberdade positiva, como possibilidades e capacidades de participação nos processos políticos; e liberdade como não dominação, não ter a possibilidade de sofrer interferências discricionárias (PETTIT, 1999).

Destaque-se, no entanto, que, no que respeita às duas revoluções do século XVIII, estas se constituíram como momentos fortes não apenas para a consolidação do conceito de República como um conjunto de valores, mas, sobretudo, como um regime político alternativo à monarquia. Assim, o republicanismo que se afirmou nos Estados Unidos, de forma permanente, e na França, de forma intermitente até o final do século XIX, foi uma versão que propugnava muito mais a ideia da virtude e da liberdade, no seu sentido negativo e de não sofrer interferências discricionárias. Como destaca Gordon Wood (2011), a Constituição aprovada em 1787 nos Estados Unidos corrobora a ideia de controle e restrição à democracia de intensa participação popular, conforme aconteceu nos estados, nos primeiros anos pós-independência. Na França, verificou-se processo similar, seja nas monarquias estabelecidas ao longo do século XIX, seja por suas sucessoras, a Segunda (1848-1852) e a Terceira (1870-1940) Repúblicas.

Tal fator está ligado ao terceiro elemento a ser destacado: as condições de cidadania ou, em outras palavras, a definição sobre o que é ser cidadão. O republicanismo coloca a condição de liberdade, em suas vertentes acima expostas, como central para a vida coletiva. Só existirá um corpo político organizado coletivamente na medida em que os seus partícipes forem livres. Neste aspecto, as diversas matrizes modernas do republicanismo, tributárias da tradição do Renascimento, irão, majoritariamente, privilegiar a vita activa, sem deixar, no entanto, de preocupar-se - especialmente na Inglaterra e nos Estados Unidos da América - com a liberdade negativa e com a liberdade como não dominação.

Por certo, entre os processos históricos elencados, poderíamos, por exemplo, apontar que, durante a República francesa, quando liderada pelos jacobinos (1792-1794), outros elementos centrais da tradição republicana (explicitamente a virtude e os interesses públicos), acabaram por sobrepujar as liberdades individuais. Antes de adentrar em algumas considerações sobre este aspecto, cumpre lembrar 
a assertiva levantada por inúmeros pensadores republicanos, de que a melhor maneira de se garantir a liberdade - nas suas diversas formas de manifestação - é freando o acúmulo de poder e estabelecendo este poder sempre (seja de forma, direta, indireta ou participativa), por meio de instituições. Essas, por sua vez, deveriam ser de responsabilidade e responsivas aos cidadãos, impedindo assim a tirania e o absolutismo, constituindo-se em um tipo de organização política que, para a Antiguidade greco-romana, denominamos de governo misto e que hoje, talvez, mais acuradamente, se designa como um sistema de checks and balances.

Por fim, importa destacar o aspecto da virtude. Este se coloca, na tradição republicana, em uma dupla forma: virtude como a preocupação com os interesses públicos; mas, também, a virtude dita cívica, ou seja, a preocupação em participar dos assuntos públicos, em se fazer presente, evitando que o poder seja abduzido por algum governante ou por uma oligarquia. Por certo, especialmente na tradição norteamericana, como bem notado por Tocqueville (1977), há compreensão diversa, no sentido de se reconhecer o valor agregativo dos interesses, segundo o que o pensador francês denominou como “interesse bem compreendido”. É interessante notar, por outro lado, que a Constituição dos Estados Unidos, aprovada em 1787, diferentemente do que muitos podem ser levados a pensar, apresenta-se como uma tentativa de execução do projeto dos Pais Fundadores, de afirmar um republicanismo que afaste os riscos, para eles real e perigoso, dos excessos de democracia.

Assim, mais do que um simples elencar de conceitos - e aqui o papel da história é central - o que se buscou compreender e apontar foi, primeiramente, como essas matrizes se formaram, quais as suas ideias centrais com relação aos campos acima destacados. Entretanto, buscamos não perder de vista como, em processos históricos específicos, esses construtos conceituais se apropriaram de corpos de conhecimento que se construíam alhures e outrora, reelaborando-os e ressignificando-os segundo os objetivos políticos de determinados grupos, via de regra marcados por situações revolucionárias. Temos por certo que compreender tais processos nos ajuda a aquilatar os dilemas que os Estados nacionais e os diferentes modelos de republicanismo enfrentam, nos dias atuais, tanto a nível interno quanto a nível global.

\section{REFERÊNCIAS}

ADVERSE, H. A matriz italiana. In: BIGNOTTO, Newton (Org.). Matrizes do republicanismo. Belo Horizonte: Ed. da UFMG, 2013. p. 51-125.

ALBUQUERQUE, J. A. G. Montesquieu: sociedade e poder. In: WEFFORT, F. C. (Org.). Os clássicos da política. 13. ed. São Paulo: Ática, 2000. p. 111-120.

ARENDT, H. Entre o passado e o futuro. 5. ed. São Paulo: Perspectiva, 2002.

ARENDT, H. Sobre a Revolução. São Paulo: Companhia das Letras, 2011. 
ARRUDA, J. J. de A. A grande revolução inglesa, 1640-1780: Revolução Inglesa e Revolução Industrial na construção da sociedade moderna. São Paulo: USP; HUCITEC, 1996.

BAILYN, B. As origens ideológicas da Revolução Americana. Bauru: EDUSC, 2003.

BARROS, A. R. G.. A matriz inglesa. In: BIGNOTTO, Newton (Org.). Matrizes do republicanismo. Belo Horizonte: Ed. da UFMG, 2013. p. 127-174.

BARON, H. The Crisis of the Early Italian Renaissance. 2. ed. Princeton: Princeton University Press, 1966.

BEAUD, M. História do capitalismo: de 1500 até nossos dias. 4. ed. São Paulo: Brasiliense, 2004.

BIGNOTTO, N. Origens do republicanismo moderno. Belo Horizonte: Ed. da UFMG, 2001.

BIGNOTTO, N. Republicanismo e realismo: um perfil de Francesco Guicciardini. Belo Horizonte: Ed. da UFMG, 2006.

BIGNOTTO, N. A matriz francesa. In: BIGNOTTO, N; (Org.). Matrizes do republicanismo. Belo Horizonte: Ed. da UFMG, 2013. p. 175-229.

CARDOSO, S. Notas sobre a tradição do "governo misto". In: BIGNOTTO, N. Pensar a República. Belo Horizonte: Ed. da UFMG, 2000. p. 27-48.

CASTRO, F. L. de. História do Direito: Geral e do Brasil. 10. ed. Rio de Janeiro: Lumen Júris, 2013.

CERQUEIRA, A. L. da G.; LOPES, M. A. A Europa na Idade Moderna. Belo Horizonte: Lê, 1995.

EISENSTEIN, E. L. A revolução da cultura impressa: os primórdios da Europa moderna. São Paulo: Ática, 1998.

FINK, Z. The Classical Republicans: an Essay in the Recovery of a Pattern of Thougth in Seventeenth Century England. Illinois: Northwestern University Press, 1962.

GELDEREN, M. v.; SKINNER, Q. Republicanism: a Shared European Heritage. v. II: Values of Republicanism in Early Modern Europe. 3. ed. Cambridge: Cambridge University Press, 2006.

GOYARD-FABRE, S. O que é democracia?. São Paulo: Martins Fontes, 2003.

GUARINELLO, N. L. Cidades-estados na Antiguidade Clássica. In: PINSKY, J.; PINSKY, C. B. (Org.). História da cidadania. São Paulo: Contexto, 2003. p. 29-47.

HILL, C. O mundo de ponta-cabeça: ideias radicais durante a Revolução Inglesa de 1640. São Paulo: Companhia das Letras, 1987.

HOBSBAWM, E. J. A era das revoluçôes: Europa 1789-1848. 11. ed. Rio de Janeiro: Paz e Terra, 2000.

HUBERMAN, L. História da riqueza dos EUA: nós, o povo. 3. ed. São Paulo: Brasiliense, 1983.

KARNAL, L. Estados Unidos, liberdade e cidadania. In: PINSKY, J.; PINSKY, C. B. (Org.). História da cidadania. São Paulo: Contexto, 2003. p. 135-157.

KARNAL, L. et al. História dos Estados Unidos: das origens ao século XXI. São Paulo: Contexto, 2007.

KEANE, J. Vida e morte da democracia. São Paulo: Edições 70, 2010. 
MAQUIAVEL, N. Discursos sobre a primeira década de Tito Livio. São Paulo: Martins Fontes, 2007.

MERQUIOR, J. G. O liberalismo antigo e moderno. 3. ed. amp. São Paulo: É Realizações Editora, 2014.

MONDAINI, M. Guerras napoleônicas. In: MAGNOLI, D. (Org.). História das Guerras. São Paulo: Contexto, 2007.

MONTESQUIEU. Do espirito das leis. São Paulo: Martin Claret, 2007.

NASCIMENTO, M. M. do. Rousseau: da servidão à liberdade. In: WEFFORT, F. C. (Org.). Os clássicos da política. 13. ed. São Paulo: Ática, 2000. p. 187-200.

ODALIA, N. A liberdade como meta coletiva. In: PINSKY, J.; PINSKY, C. B. (Org.). História da cidadania. São Paulo: Contexto, 2003. p. 159-169.

OSBORNE, R. Do povo para o povo: uma nova história da democracia. Rio de Janeiro: Bertrand Brasil, 2013.

PETTIT, Ph. Republicanism: a Theory of Freedom and Government. New York: Oxford University Press, 1999.

POCOCK, J. G. A. The Machiavellian Moment: Florentine Political Thought and the Atlantic Republican Tradition. Princeton: Princeton University Press, 1975.

RAAB, F. The Rnglish Face of Machiavelli: a Changing Interpretation, 1500-1700. London: Routledge, 1965.

ROUSSEAU, J-J. Do contrato social. São Paulo: Martin Claret, 2007.

SENELLART, M. As artes de governar: do regimen medieval ao conceito de governo. São Paulo: Ed. 34, 2006.

SKINNER, Q. As fundações do pensamento politico moderno. São Paulo: Companhia das Letras, 1996.

STARLING, H. M. M. A matriz norte-americana. In: BIGNOTTO, N. (Org.). Matrizes do republicanismo. Belo Horizonte: Ed. da UFMG, 2013. p. 231-314.

THEODORO, J. Descobrimentos e renascimento. 2. ed. São Paulo: Contexto, 1991.

TOCQUEVILlE, A. de. A democracia na América. 2. ed. Belo Horizonte: Itatiaia; São Paulo: Ed. da USP, 1977.

WOOD, G. S. The Idea of America: Reflections on the Birth of the United States. New York: Penguin Press, 2011.

WOOD, G. S. A Revolução Americana. Rio de Janeiro: Objetiva, 2013.

Data de submissão: $15 / 05 / 2020$

Data de aprovação: 22/05/2020 